\title{
Finite element analysis of the effect of novel Lock Screw system preventing abutment screw loosening
}

\author{
Eun Sub Im, Jong Eun Kim, Jee Hwan Kim, Young Bum Park* \\ Department of Prosthodontics, College of Dentistry, Yonsei University, Seoul, Republic of Korea
}

Purpose: The purpose of this finite element analysis study is to introduce the novel Lock screw system and analyze its mechanical property to see if it can prevent abutment screw loosening. Materials and Methods: The Lock screw is a component tightened on the inside of the implant abutment which applies compressive force to the abutment screw head. To investigate the effect, modeling was done using CAD program and it was analyzed by finite element analysis under various load conditions. First, the preload was measured according to the tightening torque of the abutment screw then it was compared with the theoretical value to verify the analytical model. The validated analytical model was then divided into those with no external load and those with $178 \mathrm{~N}$, and the tightening torque of the lock screw was changed to $10,20,30 \mathrm{Ncm}$ respectively to examine the property of stress distribution on the implant components. Results: Using Lock screw under various loading conditions did not produce equivalent stresses beyond the yield strength of the implant components. In addition, the axial load was increased at the abutment-abutment screw interface. Conclusion: The use of Lock screw does not exert excessive stress on the implant components and may increase the frictional force between the abutment-abutment screw interface, thus it is considered to prevent loosening of the abutment screw. (J Dent Rehabil Appl Sci 2019;35(3):132-42)

Key words: finite element analysis; abutment screw loosening; preload; friction force; axial loading

\begin{abstract}
서론
임플란트 보철물은 최근 무치악 회복을 위한 보편적인 치료 중 한 가지로 자리매김하고 있다. 하지만 임플란트 를 이용한 치료는 여러가지 기계적, 생물학적 합병증을 동반하고 있다. 기계적 합병증에는 도재 파절, 보철물 나 사 풀림, 지대주 나사 풀림 및 파절 등이 있으며, 생물학 적 합병증에는 임플란트 주변 골 소실, 연조직 염증이나 증식, 열개 등이 보고되고 있다. ${ }^{1-3}$

Jemt 등은 87명을 대상으로 한 354개의 Brånemark 임 플란트 보철물에 대한 연구에서 첫 1 년 동안 가장 많이 보고된 문제점은 지대주 나사의 풀림에 의한 보철물의

*Correspondence to: Young Bum Park

Professor, Department of Prosthodontics, College of Dentistry, Yonsei University 50-1 Yonsei-ro, Seodaemun-gu, Seoul, 03277, Republic of Korea

Tel: +82-2-2228-3164, Fax: +82-2-312-3598, E-mail: drybpark@yuhs.ac.kr

Received: June 2, 2019/Last Revision: June 13, 2019/Accepted: June 15, 2019
\end{abstract}

동요라고 보고하였다. ${ }^{4}$ 또한 Goodacre 등은 지대주 자 사 풀림은 약 $6 \%$ 정도로 나타난다고 하였다. ${ }^{5}$ 지대주 나 사 풀림의 원인으로는 과도한 외력, 표면 거칠기 감소에 따른 정착 효과(settling effect), 측방력 등이 있다. ${ }^{6,7}$ 이러 한 지대주 나사 풀림은 전하중의 감소를 가져온다. Bickford는 부적절한 전하중은 진동에 의한 나사 풀림, 연결 부 분리, 연결부 미끄러짐 등을 가져올 수 있다고 하였으 며, ${ }^{3}$ 이로 인해 치과 임플란트에서는 임플란트 구성요소 의 파절을 초래할 수 있다고 보고하였다. ${ }^{8}$ 전하중을 증가 시키기 위해서는 조임회전력을 증가시키거나, 조임회전 력을 가하는 속도를 증가시키거나, 계면의 마찰계수를 감소시키는 방법을 사용할 수 있으며, 이전의 유한요소 
해석적 연구들에 따르면 마찰계수가 낮을수록 전하중이 커지는 것을 볼 수 있다. ${ }^{9-11}$

이러한 지대주 나사 풀림 현상을 방지하기 위해 본 연 구에서는 Lock screw의 개념을 소개하려고 한다. Lock screw 시스템은 지대주 내면에 나사산을 형성하고 작은 무두 나사인 Lock screw (Fig. 1D)를 체결하여 지대주 나 사의 두부에 압축력을 가하는 방식으로, 간단한 방법으 로 지대주와 지대주 나사 두부의 밑면이 만나는 계면에 서의 마찰력을 높여 지대주 나사 풀림을 방지하는 장치 이다. 따라서 본 연구에서는 유한요소해석적 방법을 통 해 Lock screw가 지대주 나사 풀림에 어떤 영향을 미치 는지 살펴보려고 하였다.

유한요소해석법은 실제와 비슷한 모형을 이용하여 역 학적인 특성을 밝히는 방법으로 복잡한 형태를 가지는 모형을 작고 간단한 여러 개의 요소(element)로 나누어 근사해를 구하고, 이를 결합하여 전체적인 결과를 얻는 방법이다. 이 방법은 1960년 초에 항공 산업에서 구조해 석을 위해 처음 개발되어 이후 열전달, 유체역학, 전자기 학 등 공학의 다양한 분야에서 사용되고 있다. ${ }^{12}$

이러한 유한요소해석법은 1976년 임플란트의 분석에 사용된 이래로 치과영역에서도 많이 사용되고 있다. 임 플란트 구성요소들과 주변 골은 그 형태가 복잡하기 때 문에 이를 분석하는데 있어 유한요소해석법은 적합한 방 법으로 알려져 있으며, 여러 변수들을 조절하여 원하는 상황에 대한 다양한 실험을 시행할 수 있는 것이 그 장점 이다. ${ }^{12}$ 따라서 유한요소해석법은 아직 제품화가 되지 않 았거나, 실제 제품을 제작하기 전 단계에서 그 제품의 효 용성을 평가하기에 유용한 방법이라고 볼 수 있다.

본 연구에서는 지대주 나사 풀림을 방지하기 위한 새 로운 Lock screw 시스템의 역학적 특성을 유한요소해석 적 방법을 통하여 살펴보았다. 이를 위해 두 단계로 구성 된 실험을 설계하였는데, 첫 번째 단계에서는 실제 사용 되는 임플란트와 유사한 3차원 유한요소모형을 설계하 고, 전하중을 구하여 이론식과 비교해 해석모형을 검증 하였다. 두 번째 단계에서는 구해진 전하중을 부여한 상 태에서 Lock screw를 적용한 후 고정체와 지대주, 지대 주와 지대주 나사 계면에서의 역학적 특성을 분석하였 다. 본 연구의 목적은 Lock screw의 사용이 지대주 나사 풀림을 방지할 수 있는지 평가하기 위함이고, 이를 위해 Lock screw의 사용이 지대주-지대주 나사 계면의 축방향 하중을 증가시킬 것이라는 가설을 검증하려고 하였다.

\section{연구 재료 및 방법}

\section{각 부의 설계}

본 연구에서는 internal conical connection 형태를 가 지는 임플란트 시스템(Superline, Dentium, Seoul, Ko$\mathrm{rea}$ )의 형태를 근거로 해석에 필요한 부분을 $\mathrm{CAD}$ 프 로그램(CATIA student V5-6R2018, Dassault, VélizyVillacoublay, France)을 사용하여 수정하여 설계하였다. 설계한 임플란트의 디자인은 Fig. 1과 같으며, 고정체와 지대주, 지대주 나사 모두 기성 임플란트의 형태를 참고 하여 설계하였으나, 해석의 단순화 및 Lock screw를 체 결하기 위해 변형시켜 설계하였다. 고정체(Fig. 1A)는 제 조사의 설계에 근거하여 직경 $4.5 \mathrm{~mm}$, 길이 $10 \mathrm{~mm}$, 내 측으로 지대주와 만나는 부분은 11 도의 경사를 가지 는 원추형 사면를 가지도록 설계하였고, 외부 나사산은 reverse buttress 형태로 $0.9 \mathrm{~mm}$ pitch를 가지도록 하였 다. 지대주(Fig. 1B)는 제조사에서 제작한 형태를 근거로 설계하였으며, 추가적으로 내면에 나사산을 형성하여, Lock screw가 체결될 수 있게 하였다. 지대주 나사(Fig. 1C)는 전체 길이 $10 \mathrm{~mm}$, 몸체 직경 $2 \mathrm{~mm}$, 두부 직경 2.6 $\mathrm{mm}$, 피치 $0.4 \mathrm{~mm}$ 인 $\mathrm{M} 2$ 나사를 기반으로 제작하였다. Lock screw (Fig. 1D)는 직경 $3 \mathrm{~mm}$ 높이 $2 \mathrm{~mm}$ 크기와 $0.5 \mathrm{~mm}$ 피치를 가지는 $\mathrm{M} 3$ 무두나사(headless screw)로

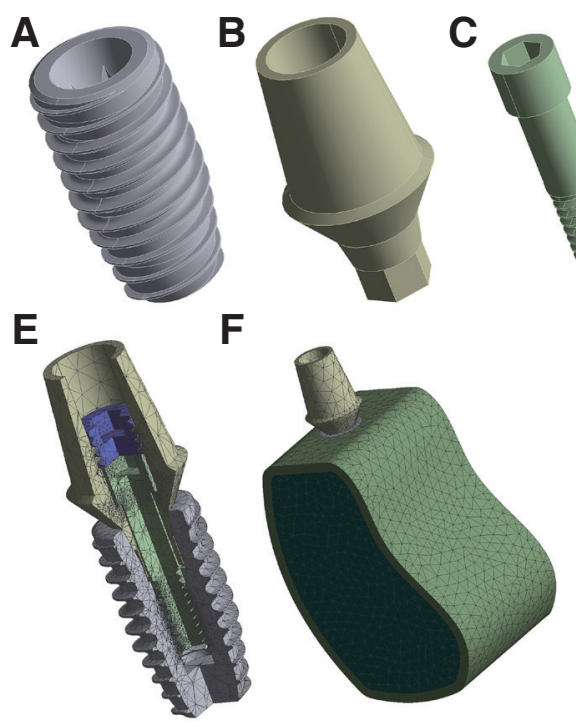

Fig. 1. Components of implant and Lock screw. (A) Fixture, (B) Abutment, (C) Abutment screw, (D) Lock screw, (E), (F) Finite element model. 
설계하였고, Lock screw가 체결되면 지대주 나사의 상부 에 압축력을 가하도록 하였다. 모든 모델은 해석상의 오 류를 피하기 위해 해석에 불필요한 부분은 배제하였다.

이후 설계한 CAD 모델을 IGES (Initial Graphics Exchange Specification) 파일로 내보내고, ANSYS SpaceClaim (ANSYS Inc., Canonsburg, USA)으로 불러 들여 해석에 필요한 수정을 하였다. 재료의 물성은 고정 체의 경우 티타늄(Grade 4), 지대주와 지대주 나사, Lock screw는 티타늄 합금(Ti-6Al-4V ELI)를 사용하였다. 골 모델은 기존 연구를 참고하여 높이 $27 \mathrm{~mm}$, 폭 $9 \mathrm{~mm}$, 너 비 $20 \mathrm{~mm}$ 의 하악골 모델을 설계하였다. ${ }^{13}$ 골 표면의 1 $\mathrm{mm}$ 는 피질골로 하였으며, 내부에는 해면골이 되도록 하 였다. 해석에 사용한 모형은 모두 등방성, 균질성 및 선형 탄성을 가정하였고, 연구에 사용한 재료의 물성은 기존 연구를 참고하였으며 상기 내용을 정리하면 Table 1과 같다. ${ }^{11,12,14,15}$

\section{유한요소해석 모형}

유한요소해석은 ANSYS Workbench 17.0 (ANSYS Inc., Canonsburg, USA)을 사용하였다. 실험은 두 단계 로 이루어져 있는데, 첫 번째 단계는 유한요소해석 모델 의 검증이고, 두 번째 단계는 Lock screw 체결 시 임플란 트 구성요소들의 역학적 특성을 살펴보는 단계이다. 먼 저 유한요소해석 모델의 타당성을 검증하고자 세 가지 마찰계수를 이용하여 전하중의 이론값을 구하고 이를 골 과 고정체, 지대주, 지대주 나사 모델을 이용하여 유한요 소해석으로 계산된 값과 비교하였다. 검증된 모델에서 측정된 전하중 값을 이용하여 지대주 나사에 전하중을 부여하고, Lock screw를 각기 다른 조임회전력으로 체결 한 후 각각에 대하여 교합력을 가하는 경우의 등가응력 (von Mises stress), 수직응력(normal stress)을 평가하여 Lock screw가 임플란트 구성요소에 미치는 영향을 살펴
보고, 외부 하중 하에서 어떤 응력분포를 가지는지 살펴 보았다.

해석에 사용된 유한요소는 해석상 중요한 부분인 나사 산과 Lock screw의 접촉부를 상대적으로 조밀하게 형성 하였고, 총 요소 229,115 개, 절점 360,752 개가 형성되었 다. 형성된 유한요소 모형의 절점 및 요소의 수는 Table 2 에 나타내었다.

\section{전하중의 이론적 계산}

지대주 나사의 조임에 의해 발생하는 전하중의 이론적 계산은 다음에 제시된 Bickford의 식을 이용하여 계산하 였다. ${ }^{8}$

$$
T_{\text {in }}=F_{P}\left(\frac{P}{2 \pi}+\frac{\mu_{t} r_{t}}{\cos \beta}+\mu_{n} r_{n}\right)
$$

여기서 $T_{i n}$ 은 조임회전력, $F_{p}$ 는 전하중, $P$ 는 나사의 피 치, $\mu_{t}$ 는 지대주 나사의 나사산에서의 마찰계수 $r_{t}$ 는 나사 산의 유효 반지름, $\beta$ 는 나사산의 각도의 절반, $\mu_{n}$ 은 나사 의 두부와 지대주가 만나는 계면에서의 마찰계수, $r_{n}$ 은 나사의 두부와 지대주가 만나는 유효 반지름을 뜻한다.

Table 2. Number of elements and nodes

\begin{tabular}{lrr}
\hline \multicolumn{1}{c}{ Geometry } & Elements & Nodes \\
\hline Cortical bone & 10,825 & 20,890 \\
Cancellous bone & 24,135 & 39,113 \\
Fixture & 82,478 & 123,486 \\
Abutment & 40,696 & 63,776 \\
Abutment screw & 58,289 & 89,869 \\
Lock screw & 9,160 & 18,087 \\
Total & 225,583 & 355,221 \\
\hline
\end{tabular}

Table 1. Properties of materials

\begin{tabular}{lccccc}
\hline & Size & Materials & Poisson's ratio & Young's modulus & Yield strength \\
\hline Cortical bone & - & - & 0.3 & $13.7 \mathrm{GPa}$ & - \\
Cancellous bone & - & - & 0.3 & $1.37 \mathrm{GPa}$ & - \\
Fixture & $\Phi 4.5 \times \mathrm{L} 10 \mathrm{~mm}$ & Titanium grade 4 & 0.34 & $105 \mathrm{GPa}$ & $483 \mathrm{MPa}$ \\
Abutment & $\Phi 5.5 \times \mathrm{H} 5.5 \mathrm{~mm}$ & & & \\
Abutment screw & $\mathrm{M} 2.0 \times 0.4 \mathrm{P}$ & Titanium alloy & 0.342 & $113 \mathrm{GPa}$ & $795 \mathrm{MPa}$ \\
Lock screw & $\mathrm{M} 3.0 \times 0.5 \mathrm{P}$ & (Ti-6Al-4V ELI) & & & \\
\hline
\end{tabular}




\section{경계조건}

골과 고정체는 완전한 골유착을 가정하여 bonded 조 건을 설정하였고, 골의 근원심 단면은 fixed support로 설 정하여 하중에 따른 변위가 발생하지 않도록 하였다. 고 정체와 지대주는 인장력에만 분리되고 마찰은 일어나지 않는 rough 조건을 사용하였다. 지대주 나사 두부와 지 대주의 접촉계면, 지대주 나사와 고정체 접촉계면, Lock screw와 지대주 나사 접촉계면, Lock screw와 지대주 접 촉계면은 모두 마찰력이 발생할 수 있는 frictional 조건 을 사용하였고, 이전 연구를 참고하여 윤활되지 않은 티 타늄 표면을 상정하여 마찰계수 $\mu=0.4$ 를 사용하였다. ${ }^{16}$ 경계조건에 대한 모식도는 Fig. 2와 같다.

\section{전하중의 유한요소해석적 측정}

유한요소해석 모델의 타당성을 검증하기위해 전하중 에 대한 해석을 시행하였다. 해석모델 중 고정체, 지대주, 지대주 나사만 불러들여 지대주 나사 상부의 육각 홈에

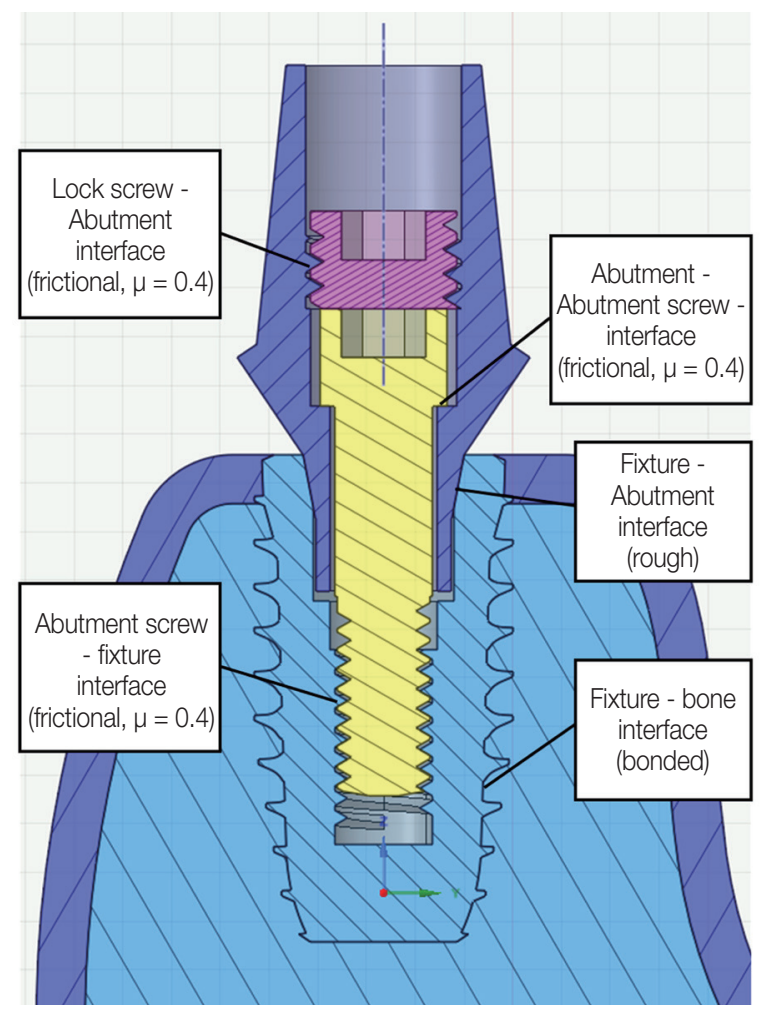

Fig. 2. Boundary condition.
ANSYS의 Moment 기능을 이용하여 시계방향으로 30 $\mathrm{Ncm}$ 의 조임회전력을 가하였다. 이때 실제 임상적 상황 과 유사하도록 조임회전력을 1 초간 증가시켰다가 1 초간 감소시키는 방식으로 가하여 잔류응력만 남도록 하였다. 검증을 위해 마찰계수 $\mu$ 는 $0.2,0.3,0.4$ 세 가지를 이용하 였다. 전하중 측정을 위해 ANSYS의 Force Reaction 기 능을 사용하였고, 측정은 검증을 위해 각각 지대주-지대 주 나사 계면과 고정체-지대주 계면에서 이중으로 시행 하였다.

\section{Lock screw의 적용 및 외부 하중부여}

Lock screw 적용은 해석의 오차를 줄이기 위해 지대주 나사의 몸체에 Bolt Pretention의 Adjustment 기능을 이 용하여 앞서 해석된 $\mu=0.4$ 일때의 전하중 값과 동일한 값을 가지는 변형량을 설정하여 시행하였다. 전하중 부 여 후 Lock screw의 상부 육각 홈에 Moment 기능을 이 용하여 시계방향으로 각각 $10 \mathrm{Ncm}, 20 \mathrm{Ncm}, 30 \mathrm{Ncm}$ 의 각기 다른 조임회전력을 가하였다. 실제 임상적 상황을 유사하게 재현하기 위해 지대주 나사와 마찬가지로 조임 회전력을 1 초간 증가 후 1 초간 감소시켰다. 또한 교합력 하에서의 응력분포를 평가하기 위해 기존 연구를 참고하 여 Lock screw 체결 후 지대주의 상부부터 변연까지의 외 면에 $178 \mathrm{~N}$ 의 외부 하중을 장축에 30도 방향으로 가하 였다. ${ }^{17,18}$ 각각의 하중조건에서 발생하는 고정체-지대주 계면과 지대주-지대주 나사 계면에서의 수직응력, 임플 란트 구성요소의 등가응력을 측정하였다.

\section{결과}

이론식과 유한요소해석을 통해 얻은 $\mu$ 값에 따른 전하 중 값을 Table 3 에 나타내었다. 지대주-지대주 나사 계면 과 고정체-지대주 계면에서 얻어진 전하중 값은 동일하 였고 이론값과 해석값은 최대 약 $14 \mathrm{~N}$ 의 정도의 차이를 보였다.

해석된 전하중 값을 바탕으로 Bolt Pretention 기능에 서 $0.012497 \mathrm{~mm}$ 만큼 지대주 나사의 몸체를 압축시켜 $303.77 \mathrm{~N}$ 의 전하중을 구현하였다. 전하중이 부여된 상태 에서 Lock screw를 각각 다른 조임회전력으로 체결하였 을 때 지대주-지대주 나사 계면과 고정체-지대주 계면에 서의 축방향 하중(axial load)을 Table 4에 나타내었다. 지 대주-지대주 나사 계면에서 축방향 하중은 조임회전력이 
Table 3. Preload values calculated by theoretical formula and measured from FEA

\begin{tabular}{cccc}
\hline Friction coefficient & $\begin{array}{c}\text { Theoretical formula } \\
(\mathrm{N})\end{array}$ & $\begin{array}{c}\text { Fixture-Abutment interface } \\
(\mathrm{N})\end{array}$ & $\begin{array}{c}\text { Abutment-Abutment screw interface } \\
(\mathrm{N})\end{array}$ \\
\hline 0.2 & 594.51 & 587.14 & 587.14 \\
0.3 & 413.75 & 405.57 & 405.57 \\
0.4 & 317.28 & 303.77 & 303.77 \\
\hline
\end{tabular}

Table 4. Axial load according to different tightening torque of Lock screw

\begin{tabular}{|c|c|c|c|}
\hline & Tightening torque of Lock screw & $\begin{array}{c}\text { Abutment-Abutment screw } \\
\text { interface }(\mathrm{N})\end{array}$ & $\begin{array}{l}\text { Fixture-Abutment } \\
\text { interface }(\mathrm{N})\end{array}$ \\
\hline \multirow{4}{*}{ No external load } & No Lock screw (preload) & 303.77 & 303.77 \\
\hline & $10 \mathrm{Ncm}$ & 377.10 & 294.29 \\
\hline & $20 \mathrm{Ncm}$ & 450.74 & 284.84 \\
\hline & $30 \mathrm{Ncm}$ & 525.74 & 275.26 \\
\hline \multirow{4}{*}{ Under external load } & No Lock screw & 286.80 & 440.95 \\
\hline & $10 \mathrm{Ncm}$ & 393.54 & 427.08 \\
\hline & $20 \mathrm{Ncm}$ & 467.58 & 417.54 \\
\hline & $30 \mathrm{Ncm}$ & 542.85 & 408.65 \\
\hline
\end{tabular}

$10 \mathrm{Ncm}, 20 \mathrm{Ncm}, 30 \mathrm{Ncm}$ 으로 증가함에 따라 $377.10 \mathrm{~N}$, $450.74 \mathrm{~N}, 525.74 \mathrm{~N}$ 으로 증가하는 경향을 보였다. 고정체지대주 계면에서 축방향 하중은 조임회전력이 증가함에 따라 294.29 N, 284.84 N, 275.26 N으로 감소하였으며, 이 러한 축방향 하중 분포를 Fig. 3에 실선으로 나타내었다.

임플란트의 구성요소에서 Lock screw의 조임회전력에 따른 등가응력 분포 및 최대 등가응력의 위치를 Fig. $4 \mathrm{~A}$ - 4D에 나타내었고, 이 때의 최대 등가응력 값을 Table 5 에 나타내었다. 고정체에서는 Lock screw의 조임회전력 증가에 따라 최대 등가응력이 감소하였고 그 위치는 첫 번째 내부 나사산이었다. 반대로 지대주에서는 최대 등 가응력이 증가하였고, 그 위치는 지대주 나사와 만나는 계면이었다. 지대주 나사에서도 최대 등가응력이 증가하 였고, 그 위치는 지대주 나사가 지대주와 만나는 계면이 었다. 모든 구성요소에서 항복강도를 넘어서는 등가응력 은 발생하지 않았다.

Lock screw 체결 후 외부 하중 적용 시 지대주-지대주 나사 계면과 고정체-지대주 계면에서의 축방향 하중을 Table 4에 제시하였다. 외부 하중을 적용한 경우에도 지 대주-지대주 나사 계면에서의 축방향 하중은 Lock screw 가 없는 경우와 조임회전력이 $10 \mathrm{Ncm}, 20 \mathrm{Ncm}, 30 \mathrm{Ncm}$
으로 증가하는 경우에서 $287.20 \mathrm{~N}, 393.54 \mathrm{~N}, 467.58 \mathrm{~N}$, 542.85 N으로 증가하는 경향을 보였다. 지대주-지대주 나사 계면에서는 외부 하중을 적용하면 그렇지 않은 경 우에 비해 축방향 하중이 감소하였고, Lock screw 체결 시에는 전하중만 부여한 것에 비해 축방향 하중이 증가 하였다. 고정체-지대주 계면에서는 축방향 하중이 같은 순서로 $440.91 \mathrm{~N}, 427.08 \mathrm{~N}, 417.54 \mathrm{~N}, 408.65 \mathrm{~N}$ 으로 감 소하였다. 이러한 축방향 하중 분포를 Fig. 3에 점선으로 나타내었다.

전하중 그리고 외부 하중 하에서 지대주 나사에 발생 하는 수직 응력 분포와 지대주-지대주 나사 계면의 수직 응력 분포는 Fig. 5와 같다. 전하중만 부여하였을 때에 는 계면에서 발생하는 수직 응력이 Fig. 5A와 같이 동심 원 모양으로 일정한 분포를 보이지만 외부 하중을 가하 면 Fig. $5 \mathrm{~B}$ 와 같이 하중의 반대 방향인 오른쪽에서 부분 적으로 압축력이 감소하는 것을 볼 수 있다. Lock screw 를 체결하는 경우(Fig. $5 \mathrm{C}, 5 \mathrm{D}, 5 \mathrm{E})$ 에는 전하중만 부여했 던 경우보다 전체적으로 더 큰 압축력이 가해졌다.

외부 하중 하에서 Lock screw의 조임회전력에 따른 임 플란트 구성요소의 등가응력 분포 및 최대 등가응력의 위치를 Fig. $4 \mathrm{E}-4 \mathrm{G}$ 에 나타내었고, 최대 등가응력 값을 


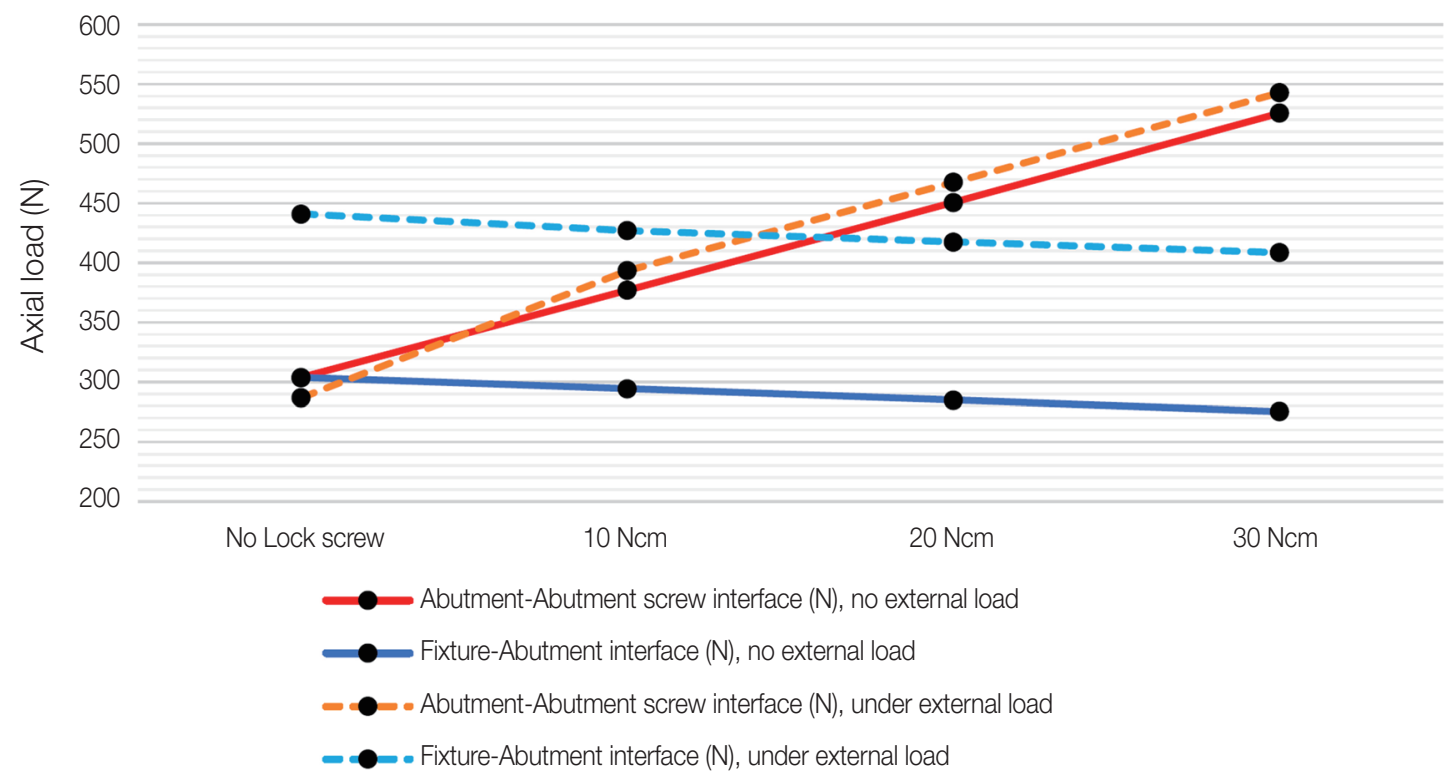

Fig. 3. Axial load according to different tightening torque of Lock screw.

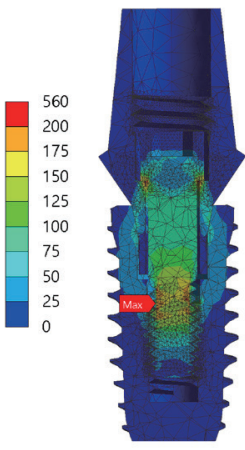

A

No Lock screw

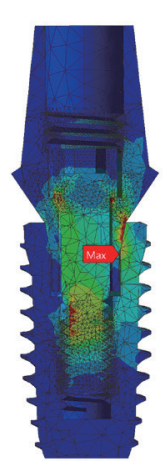

E

No Lock screw

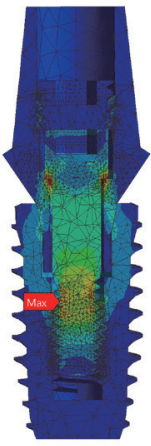

B

$10 \mathrm{Ncm}$

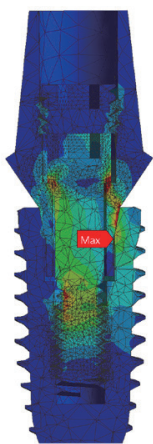

$\mathbf{F}$

$10 \mathrm{Ncm}$

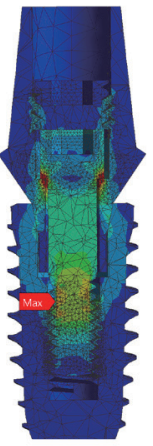

C

$20 \mathrm{Ncm}$

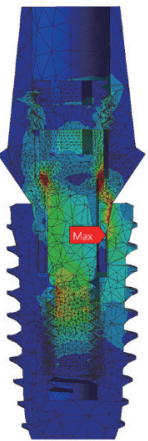

G

$20 \mathrm{Ncm}$

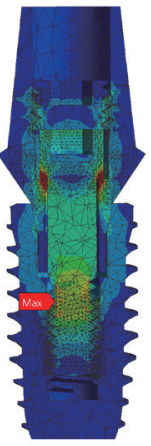

D

$30 \mathrm{Ncm}$

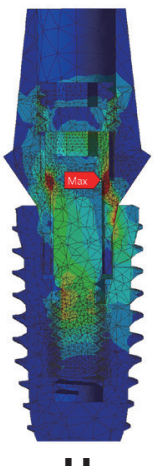

$\mathrm{H}$

$30 \mathrm{Ncm}$

Fig. 4. von Mises stress distribution according to tightening torque of Lock screw. (A - D) No external load, (E-H) Under external load.

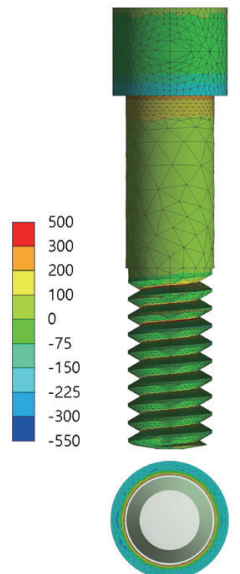

A

No external load

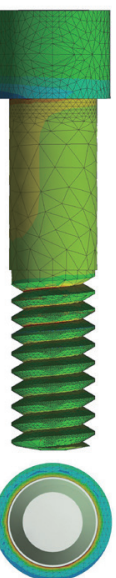

B

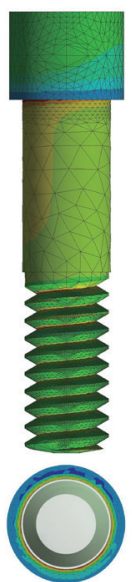

C
No Lock $10 \mathrm{Ncm} \quad 20 \mathrm{Ncm} \quad 30 \mathrm{Ncm}$

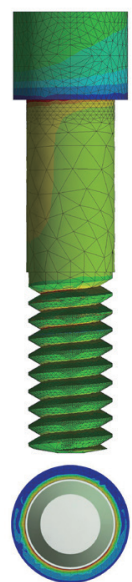

D

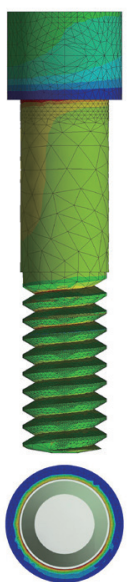

E screw

Fig. 5. Normal stress of abutment screw and abutmentabutment screw interface under external load.

Table 5에서 나타내었다. 구성요소 별로 최대 등가응력 의 증감과 그 위치를 살펴보면 고정체에서는 Lock screw 의 조임회전력 증가에 따라 최대 등가응력이 감소하였고 그 위치는 첫 번째 내부 나사산이었다. 지대주에서는 최 대 등가응력이 Lock screw가 없는 경우와 $10 \mathrm{Ncm}, 20$ $\mathrm{Ncm}$ 에서는 $557.40 \mathrm{~N}, 537.70 \mathrm{~N}, 526.54 \mathrm{~N}$ 으로 감소하 였고, 그 위치는 지대주와 고정체가 만나는 경사면의 하 
Table 5. Maximum von Mises stress according to different tightening torque of Lock screw

\begin{tabular}{llcccc}
\hline & $\begin{array}{l}\text { Tightening torque of } \\
\text { Lock screw }\end{array}$ & $\begin{array}{c}\text { Fixture } \\
(\mathrm{MPa})\end{array}$ & $\begin{array}{c}\text { Abutment } \\
(\mathrm{MPa})\end{array}$ & $\begin{array}{c}\text { Abutment screw } \\
(\mathrm{MPa})\end{array}$ & $\begin{array}{c}\text { Lock screw } \\
(\mathrm{MPa})\end{array}$ \\
\hline \multirow{5}{*}{ No external load } & No Lock screw & 555.85 & 295.60 & 278.48 & - \\
& $10 \mathrm{Ncm}$ & 539.33 & 342.61 & 283.57 & 66.26 \\
& $20 \mathrm{Ncm}$ & 522.90 & 391.77 & 321.07 & 131.70 \\
& $30 \mathrm{Ncm}$ & 506.35 & 443.79 & 386.49 & 324.06 \\
& No Lock screw & 556.31 & 557.40 & 316.11 & - \\
\multirow{3}{*}{ Under external load } & $10 \mathrm{Ncm}$ & 528.03 & 537.70 & 337.96 & 139.26 \\
& $20 \mathrm{Ncm}$ & 511.74 & 526.54 & 351.48 & 192.55 \\
& $30 \mathrm{Ncm}$ & 495.29 & 553.84 & 394.77 & 426.58 \\
\hline
\end{tabular}

단부였다. $30 \mathrm{Ncm}$ 에서는 최대 등가응력이 $553.84 \mathrm{~N}$ 으 로 증가하였는데, 그 위치는 지대주 나사와 만나는 계면 이었다. 지대주 나사에서는 최대 등가응력이 Lock screw 의 조임 회전력 증가에 따라 증가하였는데, Lock screw 가 없을 때에는 첫 번째 나사산이었고, Lock screw가 있 을 때에는 지대주와 만나는 계면이었다. 모든 구성요소 에서 항복강도를 넘어서는 등가응력은 발생하지 않았다.

\section{고찰}

지대주 나사의 풀림은 종종 지대주 나사의 파절을 초 래한다. ${ }^{3}$ 이를 방지하기 위해서 지대주 내면에 회전에 저 항하는 형태를 만들어주는 방법, washer를 이용하는 방 법, 지대주 나사에 코팅을 하는 방법, post screw를 이용 하는 방법 등이 제시되어 왔다. ${ }^{19-23}$ 이러한 방법들은 지대 주 나사의 회전을 물리적으로 구속하거나(저항형태, post screw), 허용 변위량을 늘리거나(washer), 마찰계수를 줄 이는 방법으로 지대주 나사의 풀림을 방지하였다. 본 연 구에서 새롭게 제시한 Lock screw는 지대주 나사위에 체 결함으로써 지대주 나사 두부의 물리적인 구속과 마찰력 을 높이는 방법을 사용하였다. 상용화된 제품이 없기 때 문에 Lock screw가 어떤 역학적 거동을 보이는지 알아보 기 위해 유한요소 해석적 방법을 사용하였다.

지대주 나사에 부여되는 전하중의 크기는 앞서 언급한 대로 Bickford의 식을 따르는데, 식에서 사용된 변수들 중 대부분은 임플란트의 설계상 조절 범위가 크지 않다. 따라서 이 중 가장 크게 전하중을 변화시키는 것은 조임 회전력과 마찰계수라고 할 수 있는데, ${ }^{8,9}$ 한 유한요소 해 석 연구에서는 내측 연결형 임플란트에서 지대주 나사
를 각각 $10 \mathrm{Ncm}, 20 \mathrm{Ncm}, 30 \mathrm{Ncm}, 40 \mathrm{Ncm}$ 으로 체결 하였을 때 전하중은 조임회전력이 클수록 증가하는 경향 을 보인다고 하였고, 조임회전력이 $40 \mathrm{Ncm}$ 에서는 지대 주 나사의 최대 등가응력이 허용응력을 초과한다고 하였 다. ${ }^{8} \mathrm{Lang}$ 등은 유한요소해석적 방법을 이용하여 전하중 의 크기를 계산하였는데, 마찰계수를 감소시키면 전하중 의 크기가 증가한다고 하였다. ${ }^{9}$ 따라서 이론적으로는 마 찰계수를 낮추고, 조임회전력을 증가시키면 전하중을 증 가시킬 수 있다. 하지만 과도한 전하중의 부여는 지대주 나사의 허용응력을 초과하거나, 초과하지 않더라도 교합 력 하에서 가해지는 부하에 의해 지대주 나사의 파절을 초래할 수 있기 때문에 적절한 전하중 값을 가지는 것이 필요하다.

본 연구에서는 유한요소해석을 통해 측정한 마찰계수 에 따른 전하중의 값이 이론식에 의한 값과 유사한 범위 내에 존재했다. 이전의 실험실 및 유한요소 해석연구들 과 비교하였을 때 수용 가능한 정도의 차이였으며, 여러 연구에서 다양한 임플란트 구성요소의 디자인으로 인해 발생하는 전하중의 값에는 차이가 있었지만, 일반적으 로 지대주 나사에 부여되는 전하중의 값과 유사한 경향 을 보였다..$^{8-10,24}$ 이것은 본 연구에서 임플란트 구성요소 를 설계하는 과정에서 해석에 불필요한 부분을 제거하고 단순화한 모형을 사용하였기 때문이라고 볼 수 있다. 따 라서 본 3차원 유한요소 모형은 새로운 구조물인 Lock screw의 영향을 분석하기에 적절한 모형이라고 볼 수 있다.

유한요소해석에서 조임회전력을 부여하는 방법으로는 조임회전력을 가한 채로 유지시키거나, ${ }^{8}$ 회전 속도 $(\mathrm{rpm}$, rotation per minute)를 정하는 방법 등이 있었다. ${ }^{11}$ 회전 속도를 달리하는 연구에서는 각각 $15 \mathrm{rpm}$ 과 $30 \mathrm{rpm}$ 으 
로 렌치를 회전시킨 결과, $30 \mathrm{rpm}$ 으로 회전시킨 경우에 생성되는 전하중의 값이 커졌으며, 이는 회전속도의 증 가가 마찰 저항을 이기는데 유리하며, 결과적으로 마찰 계수를 줄이는 효과가 있다고 하였다. ${ }^{11}$ 하지만 임상적인 상황에서는 제조사의 지시하는 조임회전력 값을 지속적 으로 적용시키지 않기 때문에 본 연구에서는 임상적 상 황을 재현하기 위해 지대주 나사의 조임회전력을 $0 \mathrm{Ncm}$ 부터 1 초간 증가시켜 원하는 만큼 증가시키고, 다시 1 초 간 감소시켜 다시 $0 \mathrm{Ncm}$ 으로 만드는 방법을 사용하였 다. 이렇게 적용한 조임회전력에 대하여 형성되는 전하중 의 값는 이론값에 근접하였다.

본 연구에서 Lock screw를 사용하면 Fig. 4에서 나타난 것처럼 지대주-지대주 나사 계면에서 발생하는 장축방향 의 축방향 하중은 증가하였고, 고정체-지대주 계면에서 는 약간 감소하였다. 따라서 Lock screw의 조임회전력이 증가함에 따라 전하중이 약간 감소한다고 볼 수 있으나, 그 크기는 $10 \mathrm{Ncm}$ 증가시마다 약 $9.5 \mathrm{~N}$ 정도로 부여되 는 전하중의 약 $3 \%$ 정도였다. Table 4 를 살펴보면 이는 Lock screw 체결에 따라 지대주-지대주 나사 계면이 더 큰 압축력 하에 놓이게 되어 지대주의 접촉면을 하방으 로 누르게 되고, 이 과정에서의 움직임이 지대주 나사의 신장량을 줄여 전하중의 감소로 이어지는 것으로 추측된 다.

지대주-지대주 나사 계면에서의 수직응력의 증가는 지 대주 나사 두부의 회전 방지에 큰 영향을 미친다. 일반적 으로 알려진 마찰력을 구하는 식은 다음과 같다. ${ }^{25}$

$$
\mathrm{F}=\mu \mathrm{N}
$$

마찰력은 수직항력 $(\mathrm{N})$ 과 마찰계수 $(\mu)$ 의 곱에 비례하 는데, 일반적으로 마찰계수는 사용하는 물질에 따라 정 해져 있고, 수직항력은 물체의 무게에 비례한다. 하지만 지대주-지대주 나사 계면에서의 수직항력은 무게와 같 은 방향으로 작용하는 축방향 하중의 크기에 따라 결정 된다고 볼 수 있다. 따라서 Lock screw를 체결하면 마찰 계수는 변화가 없으나, 수직항력을 증가시킬 수 있기 때 문에 결과적으로 지대주-지대주 나사 계면에서의 마찰력 을 증가시킬 수 있다. 본 연구에서는 Fig. 3 에 나타난 것 처럼 Lock screw를 각각 $10 \mathrm{Ncm}, 20 \mathrm{Ncm}, 30 \mathrm{Ncm}$ 으로 체결 시 지대주-지대주 나사 계면의 축방향 하중이 Lock screw가 없을 때 보다 증가하였는데, 전하중에 비하여 30 $\mathrm{Ncm}$ 일 때 지대주-지대주 나사 계면의 축방향 하중이 약 1.73 배 증가하였다. 따라서 Lock screw를 사용하면 상당
량의 마찰력 증가가 가능하다고 볼 수 있다. 따라서 이를 통해 지대주 나사가 풀리려는 힘에 저항할 수 있게 된다.

Haack 등은 지대주 나사에서 탄성 회복으로 형성된 인 장력이 고정체와 지대주에 고정력(clamping force)으로 작용한다고 하였다. 하지만 지대주에 장축 방향으로 교 합력과 같은 압축력이 작용하면 고정하는 효과가 감소 하거나 소실되는데, 이는 지대주-지대주 나사의 계면이 분리 때문이라고 하였다. 또한 지대주에 비스듬한 방향 으로 가해지는 힘은 지대주-지대주 나사 계면에서 편심 하중(eccentric load)을 발생시키고, 이는 지대주 나사의 풀림을 진행시킨다고 하였다. 따라서 추가적인 전하중의 증가가 지대주 나사의 계면 분리를 막을 수 있다고 하였 다. ${ }^{24}$

본 연구에서 외부 하중 하에서 지대주 나사 및 지대주지대주 나사 계면에서 수직 응력의 분포는 Fig. 5 와 같다. 외부 하중만 작용하는 경우(Fig. $5 \mathrm{~B}$ )에는 지대주 나사의 두부에서 부분적으로 압축력이 감소하는 부분이 나타난 다. 여기에 Lock screw를 체결하게 되면 지대주 나사의 두부가 전반적인 압축응력 하에 놓이게 되며, 이는 지대 주 나사가 지대주를 누르는 힘을 증가시키게 된다. 지대 주-지대주 나사 계면에서는 Lock screw가 없는 경우 전 하중만 작용하면 Fig. $5 \mathrm{~A}$ 와 같이 동심원 모양의 수직 응 력 분포를 보이게 된다. 하지만 경사진 외부 하중이 작용 하면 Fig. $5 \mathrm{~B}$ 와 같이 편향된 수직 응력 분포를 보이게 된 다. 특히 이 경우에는 계면에서 편심 하중을 발생시켜 외 부하중이 작용하는 반대 방향에서 부분적으로 압축력 이 낮아지게 된다. 이 때 전체적인 축방향 하중은 Fig. 3 에 제시된 것처럼 약간의 감소가 일어나게 된다. 하지만 Lock screw를 체결하게 되면 이 부분에 충분한 축방향 하중을 부여해줄 수 있고, 계면의 분리를 막아 지대주 나 사 풀림을 방지할 수 있을 것으로 보인다. 또한 $30 \mathrm{Ncm}$ 의 조임회전력을 사용하는 것이 가장 큰 효과를 가져올 것으로 예상할 수 있다.

본 연구에서 다양한 조건 하에서 등가 응력은 Fig. 4 및 Table 5에 나타나 것과 같다. 최대 등가 응력은 Lock screw를 사용하지 않고 교합력만 작용한 경우에 지대주 에서 $557.40 \mathrm{MPa}$ 로 나타났으며, 이는 지대주에 사용한 물질인 티타늄 합금의 항복강도인 $795 \mathrm{MPa}$ 에 비해 낮은 값이었다. 따라서 주어진 조건 하에서 지대주 나사에 사 용하는 조임회전력인 $30 \mathrm{Ncm}$ 을 Lock screw에 사용하는 데 무리가 없다고 추론할 수 있다.

하지만 Lock screw를 사용하는 데 있어 예상되는 몇 
가지 문제점이 있다. 먼저 비용적인 측면에서 직경 $3 \mathrm{~mm}$, 높이 $2 \mathrm{~mm}$ 의 매우 작은 부품을 추가적으로 사용해야 하 며, 지대주 내부에 이를 체결하기 위한 나사산 가공이 추 가로 필요하다는 점에서 임플란트 제작 비용 증가를 가 져올 수 있다. 그리고 지대주 내면에 나사산을 형성함으 로 인해 지대주의 두께가 얇아져 강도가 하락할 수 있으 므로 추가적인 보강이 필요할 것으로 보인다. 또한 Lock screw가 파절되거나 나사산이 마모되는 경우 제거가 어 려울 수 있기 때문에 신뢰성 있는 재질로 제작해야 할 것 으로 생각된다. 최근 많이 사용되고 있는 맞춤형 지대주 를 사용하는 경우나 지대주 각도를 수정하여 가공하는 경우에는 Lock screw 체결을 위한 충분한 지대주 높이 를 확보하는 것이 불가능할 수 있다. 따라서 이러한 예상 되는 문제점에 대해서는 추가적인 연구가 필요할 것으로 생각된다.

본 연구는 유한요소 해석 연구의 한계를 가지고 있다. 또한 실제 임상적 상황에서 발생할 수 있는 임플란트 구 성요소의 마모, 변형, 다양한 교합력의 크기와 방향, 구강 내 환경 등을 반영할 수 없기 때문에 본 연구의 결과를 임 상에 바로 적용하는데 무리가 있다. 따라서 Lock screw 를 사용한 실험 모형에서 추가적으로 반복하중에 관한 실험이나 임상실험이 이루어져야 그 효용성을 판단할 수 있을 것으로 생각된다.

\section{결론}

본 연구에서는 새로운 지대주 나사 풀림 방지 방법인 Lock screw의 개념을 제시하고, 이를 3차원 유한요소해 석적 방법을 통해 그 효용성을 평가하였다. 이를 위해 일 차적으로 전하중의 이론값과 해석값을 구하여 비교함으 로써 해석 모형의 타당성을 확보하였다. 검증된 모형을 이용하여 새로운 Lock screw를 각기 다른 조임회전력으 로 사용 시 임플란트 구성요소에서 응력분포 양상을 알 아보았고, 이를 통해 Lock screw의 효용가능성을 평가해 보고자 하였다. 본 유한요소해석연구를 통하여 다음과 같은 결론을 얻었다.

1. 전하중이 부여된 상태에서 외부 하중의 작용 시 지 대주-지대주 나사 계면에서 축방향 하중의 감소가 나타난다.

2. Lock screw 사용 시 지대주-지대주 나사 계면에서 축방향 하중의 증가가 일어나며, 그 크기는 Lock screw의 조임회전력이 클수록 증가한다.
3. Lock screw 사용 시 각각의 조임회전력에서 임플란 트 구성요소에서 발생하는 최대 등가응력은 557.40 $\mathrm{MPa}$ 로 티타늄 합금의 항복강도를 넘어서지 않는다.

4. Lock screw 사용 시 약간의 전하중 감소가 일어나 며, 그 값은 Lock screw의 조임회전력이 증가함에 따라 커진다.

이상의 결과를 통해 보았을 때 Lock screw의 사용은 연구에서 사용된 조임회전력에서는 임플란트 구성요소 에 과도한 응력을 일으키지 않는다. 또한 Lock screw의 사용은 지대주-지대주 나사 계면의 축방향 하중 증가를 통해 마찰력 증가를 가져와 지대주 나사 풀림 현상을 방 지할 수 있을 것으로 판단된다.

\section{ORCID}

Eun Sub Im https://orcid.org/0000-0003-2073-0038

Jong Eun Kim https://orcid.org/0000-0002-7834-2524

Jee Hwan Kim https://orcid.org/0000-0002-0872-4906

Young Bum Park https://orcid.org/0000-0003-4177-1947

\section{References}

1. Goodacre CJ, Bernal G, Rungcharassaeng K, Kan JY. Clinical complications with implants and implant prostheses. J Prosthet Dent 2003;90:121-32.

2. Goodacre CJ, Kan JY, Rungcharassaeng K. Clinical complications of osseointegrated implants. J Prosthet Dent 1999;81:537-52.

3. Schwarz MS. Mechanical complications of dental implants. Clin Oral Implants Res 2000;11 Suppl 1:156-8

4. Jemt T, Lindén B, Lekholm U. Failures and complications in 127 consecutively placed fixed partial prostheses supported by Brånemark implants: from prosthetic treatment to first annual checkup. Int J Oral Maxillofac Implants 1992;7:40-4.

5. Hemmings KW, Schmitt A, Zarb GA. Complications and maintenance requirements for fixed prostheses and overdentures in the edentulous mandible: a 5-year report. Int J Oral Maxillofac Implants 1994;9:191-6.

6. Winkler S, Ring K, Ring JD, Boberick KG. Implant screw mechanics and the settling effect: overview. J Oral Implantol 2003;29:242-5. 
7. Jörnéus L, Jemt T, Carlsson L. Loads and designs of screw joints for single crowns supported by osseointegrated implants. Int J Oral Maxillofac Implants 1992;7:353-9.

8. Bickford JH. An introduction to the design and behavior of bolted joints. 2nd ed. New York; Marcel Dekker; 1990. p. 127-35.

9. Lang LA, Kang B, Wang RF, Lang BR. Finite element analysis to determine implant preload. J Prosthet Dent 2003;90:539-46.

10. Jörn D, Kohorst P, Besdo S, Rücker M, Stiesch M, Borchers L. Influence of lubricant on screw preload and stresses in a finite element model for a dental implant. J Prosthet Dent 2014;112:340-8.

11. Bulaqi HA, Mousavi Mashhadi M, Geramipanah F, Safari H, Paknejad M. Effect of the coefficient of friction and tightening speed on the preload induced at the dental implant complex with the finite element method. J Prosthet Dent 2015;113:405-11.

12. Geng JP, Tan KB, Liu GR. Application of finite element analysis in implant dentistry: a review of the literature. J Prosthet Dent 2001;85:585-98.

13. Lee YS, Kang KT, Han DH. The non-linear FEM analysis of different connection lengths of internal connection abutment. J Korean Acad Prosthodont 2016;54:110-9.

14. McCracken M. Dental implant materials: commercially pure titanium and titanium alloys. J Prosthodont 1999;8:40-3.

15. Eom TG, Suh SW, Jeon G-R, Shin JW, Jeong CM. Effect of Tightening Torque on Abutment-Fixture Joint Stability using 3-Dimensional Finite Element Analysis. J Korean Acad Prosthodont 2009;47:12535.

16. Budinski KG. Tribological properties of titanium alloys. Wear 1991;151:203-17.
17. Hsu ML, Chen FC, Kao HC, Cheng CK. Influence of off-axis loading of an anterior maxillary implant: a 3-dimensional finite element analysis. Int J Oral Maxillofac Implants 2007;22:301-9.

18. Park CW, Kim SH, Yeo IS, Yoon HI, Han JS. Three-dimensional finite element analysis according to the insertion depth of an immediately loaded implant in the anterior maxilla. J Korean Acad Prosthodont 2018;56:105-13.

19. Korioth TW, Cardoso AC, Versluis A. Effect of washers on reverse torque displacement of dental implant gold retaining screws. J Prosthet Dent 1999;82:312-6.

20. Versluis A, Korioth TW, Cardoso AC. Numerical analysis of a dental implant system preloaded with a washer. Int J Oral Maxillofac Implants 1999;14:337-41.

21. Martin WC, Woody RD, Miller BH, Miller AW. Implant abutment screw rotations and preloads for four different screw materials and surfaces. J Prosthet Dent 2001;86:24-32.

22. Aboyoussef H, Weiner S, Ehrenberg D. Effect of an antirotation resistance form on screw loosening for single implant-supported crowns. J Prosthet Dent 2000;83:450-5.

23. Kim JH, Lim JH, Cho IH, Lee JS. A study of the anti-rotating inner post screw system as a means of preventing abutment screw loosening. J Korean Acad Prosthodont 2005;43:671-83.

24. Haack JE, Sakaguchi RL, Sun T, Coffey JP. Elongation and preload stress in dental implant abutment screws. Int J Oral Maxillofac Implants 1995;10:52936.

25. Halliday D. Fundamentals of Physics. 10th ed. New Jersey; Wiley; 2013. p. 124-7. 


\section{지대주 나사 풀림 방지를 위한 새로운 Lock Screw 시스템의 효과에 대한 유한요소해석적 연구}

\section{임은섭, 김종은, 김지환, 박영범*}

연세대학교 치과대학 보철과학교실

목적: 본 유한요소해석적 연구는 새로운 Lock screw 시스템을 소개하고 그 역학적 특성을 분석하여 Lock screw가 지대 주 나사 풀림을 방지할 수 있는지 알아보려고 한다.

연구 재료 및 방법: Lock screw는 임플란트 지대주 내부에 체결하여 지대주 나사 두부에 압축력을 가하는 장치이다. 그 효과를 알아보기 위해 CAD 프로그램을 이용하여 모델링을 하였고, 이를 다양한 하중조건 하에서 유한요소해석법을 이 용해 분석하였다. 우선 지대주 나사의 조임회전력에 따른 전하중을 측정하고 이론 값과 비교하여 해석모델을 검증하였 다. 검증된 해석 모델을 외부 하중이 없는 것과 $178 \mathrm{~N}$ 을 부여한 것으로 나누어 Lock screw의 조임회전력을 각각 10,20 , $30 \mathrm{Ncm}$ 으로 변화시켰고, 이때 임플란트 구성요소의 응력 분포가 어떠한 특성을 보이는지 살펴보았다.

결과: 여러 하중조건 하에서 Lock screw의 사용은 임플란트 구성요소의 항복강도를 넘어서는 등가응력을 발생시키지 않았다. 또한 지대주-지대주 나사 계면에서 축방향 하중의 증가를 보였다.

결론: Lock screw의 사용은 임플란트 구성요소에 과도한 응력을 가하지 않으며, 지대주-지대주 나사 계면의 마찰력을 증가시켜 지대주 나사 풀림을 방지할 수 있을 것으로 판단된다.

(구강회복응용과학지 2019;35(3): 132-42)

주요어: 유한요소해석; 지대주 나사 풀림; 전하중; 마찰력; 축방향 하중

*교신저자: 박영범

(03722) 서울특별시 서대문구 연세로 50-1 연세대학교 치과대학 보철과학교실

Tel: 02-2228-3164 | Fax: 02-312-3598 | E-mail: drybpark@yuhs. ac.kr

접수일: 2019년 6월 2일 | 수정일: 2019년 6월 13일 | 채택일: 2019년 6월 15일 